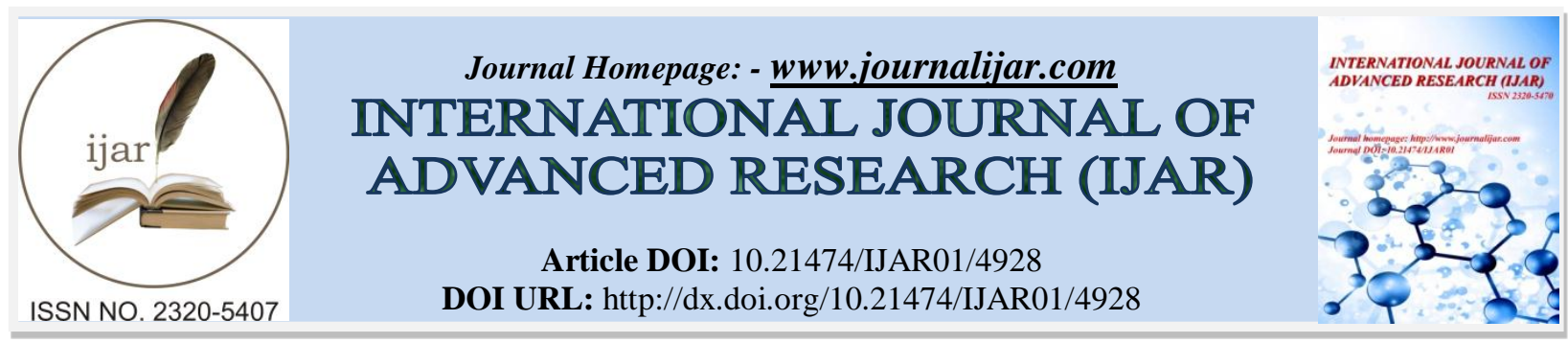

RESEARCH ARTICLE

\title{
THE EFFECT OF SOLIDITY AND INTEGRITY ON PROFESSIONALISM AND THE IMPACT OF PROFESSIONALISM ON INTEGRITY LEADERSHIP OF INDONESIA NATIONAL ARMY OF GROUND FORCE.
}

\author{
Mohammad Zaini ${ }^{1}$, Zaenal Fanani ${ }^{2}$ and Mohammad Soleh ${ }^{2}$. \\ 1. Students Magister Program of National Defense of Postgraduate Program Brawijaya University. \\ 2. Lecturer Magister Program of National Defense of Postgraduate Program of Brawijaya University.
}

\section{Manuscript Info}

Manuscript History

Received: 23 May 2017

Final Accepted: 25 June 2017

Published: July 2017

\section{Abstract}

Solidity is a condition (or a character). The root of this word is "solid" meaning as sturdy or been fully-loaded. The solidity of soldiers, therefore, describes a condition where soldiers have sturdiness and are fully-loaded with required capacities in military organization. For dealing with problems and heavy challenges in the future, therefore, solidity, cohesiveness and corp spirit of Indonesia National Army of Ground Force (TNI-AD) must be increased. Integrity is a key character of a certain soldier based on its rank level. Integrity is a first condition in choosing leader, and then followed by intelectual and managerial capabilities of TNI-AD.

The objective of research is to analyze the effect of solidity and integrity on professionalism and the impact of professionalism on integrity leadership of TNI-AD; and also to investigate the model with the dominant effect of solidity and integrity on professionalism, and the impact of professionalism on integrity leadership of TNI-AD. The location of research is at Pusdik Arhanud addressed at Karangploso Road, Malang Regency. Time of research begins from 18 January 2017 to 21 March 2017, or lasting for 3 months. Type of research is quantitative with field survey. The sample of research includes 150 persons, and data analysis is using Structural Equation Modeling (SEM) with Software WarpPLS 5.0.

Result of research explains that solidity and integrity have an effect of $71.2 \%$ on professionalism. Solidity is represented by feeling as having similar fate and profession. Moreover, the effect of professionalism on integrity leadership is rated for $81 \%$. Normative integrity has the highest load, meaning that it has positive and significant effect. The form of integrity in this paper is soldiers' sense of authority. Integrity represented by soldiers' sense of authority has a positive effect on charismatic integrity leadership. The effect of professionalism would increase integrity leadership where the increase of their self-identity and their chance to develop among TNI-AD soldiers may go along with the increase of integrity leadership. It is suggested that activities supporting the solidity must be closely related to the integrity of leader because it is needed to avoid polemic that occurs in the

Corresponding Author:- Mohammad Zaini.

Address:- Students Magister Program of National Defense of Postgraduate Program Brawijaya 
information age. It may help to change soldiers' mindset that is previously unmanaged. This change covers attitude, mentality, and behavior of soldiers to produce new culture that may influence their conduct of duty. Soldiers' attitude toward leader may change the existing ethic and norm professed by TNI-AD soldiers.

Copy Right, IJAR, 2017,. All rights reserved.

\section{Introduction:-}

\section{Background:-}

Professionalism among TNI soldiers is determined by political will, governmental support, and TNI enthusiasm. As stated in Article 2 Verse (d) Law No.34/2004 on TNI, the definitive concept of professional was given. Professional Army is who has been trained, educated, well prepared, without practical politic connection or business affair, but being secured for the consumption of the living standard, and following political policy in the nation that professes principles of democracy, civil supremacy, human right, national law provision, and international ratification.

Solidity is a condition (or a character). This word is rooted from "solid" meaning as sturdy or been fully-loaded. The solidity of soldiers, therefore, describes a condition where soldiers have sturdiness and are fully-loaded with required capacities in military organization. Grand Dictionary of Indonesia has stated that being strong, sturdy, and fully-loaded. A military unit with high solidity is one with strength, sturdy, and fully loaded. Someone is said as having integrity because the action as soldier has integrity. Being soldier is different from being human because human must adjust their face and appearance to personal motive and interest. Integrity becomes the key character for a soldier based on rank-level. Integrity is first condition in selecting leader, and other next condition includes intellectual and managerial capabilities. Sir John Winthrop Hackett in his book titled with "The Profession of Arms" said that "spirit of professionalism is moral integrity", meaning that professionalism is based on value, faith and principle (Wikipedia). In other words, assessing someone with integrity must consider trustworthiness of someone in keeping his word and act.

A soldier with integrity is not a human with various faces and appearances that must be conformed to any personal motives and interests. Integrity is a key character of a soldier based on his rank-level. Therefore, it is not surprising if integrity becomes a first condition to consider in selecting leader. Other condition taken into account involves intellectual and managerial capabilities. Sir John Winthrop Hackett in his book entitled with "The Profession of Arms" suggests that "spirit of professionalism is moral integrity".

Professionalism in detail can be found in a fundamental concept of professionalism. Morris Janowits as quoted by Segal and Schwartz has defined professionalism as a specialized skill acquired through intensive training, standards of ethics and performance, sense of a group identity, and better administration system. Sociologists have provided more various opinions and judgments about professionalism.

Indonesia National Army of Ground Force has attempted to excavate, to adopt, to explore, and to apply, as well as to develop the proper sciences and theories of leadership that shall be important because it helps TNI to identify leaders based on their strata and rank in pursuant with President Decree No.10/2010 about Organizational Structure of TNI. It also helps improving leadership quality of military officers who graduate from Academy of TNI, especially Military Academy. It is expected that by effective and efficient field leadership (face-to-face leadership), the lesson of leadership would be transferred into subordinate leaders to produce sustainable leadership.

\section{Problem Formulation:-}

Based on the overview of background, some problems are formulated:

1. How is the effect of solidity and integrity on professionalism and the impact of professionalism on integrity leadership of TNI-AD?

2. What model is with the most dominant effect on solidity and integrity on professionalism and the impact of professionalism on integrity leadership of TNI-AD?

\section{Objective of Research:-}

By taking account the formulated problems above, the objectives of research are explained as following:-

1. To analyze the effect of solidity and integrity on professionalism and the impact of professionalism on integrity 
leadership of TNI-AD.

2. To investigate the model with the dominant effect of solidity and integrity on professionalism, and the impact of professionalism on integrity leadership of TNI-AD.

\section{Method Of Research:-}

Time and Location of Research:-

The location of research is Pusdik Arhanud addressed at Karangploso Road in Malang Regency. Research starts from 18 January 2017 to 21 March 2017, or lasting for 3 months.

\section{Type of Research:-}

Type of research is survey. It takes sample from population by using questionnaire as a data collection instrument (Singarimbun, 1995). Method of research is aimed to design, to look for, and to explain causal relationship between variables through hypothesis testing (explanatory research).

\section{Sampling Technique:-}

Sampling technique is total sampling because the sample includes all members or soldiers at Pusdik Arhanud in Karangploso District, Malang Regency. There are 100 persons sorted as respondent representative. The reason behind this number is that it is a result from minimally 5 times of total items in the questionnaire (Malhotra, 1995).

\section{Data Analysis Technique:-}

The analysis is conducted with Structural Equation Modeling (SEM) supported by Software WarpPLS.5. This model is selected because it can provide direct explanation about validity and reliability tests. The validity of question is an indicator that will be used to measure certain latent variable. The validity is known by testing whether all loads are significant $(\mathrm{p}<0.05)$ by t-test value greater than 1.96 , while the reliability of an indicator can be known by counting composite reliability or construct reliability with the following equation (Ghozali and Fuad, 2005):

$\rho=((\Sigma \lambda) 2) /[(\Sigma \lambda) 2+\Sigma(\theta)]$

\section{Where:- \\ $\rho=$ composite reliability \\ $\lambda=$ loading indicator \\ $\theta=$ error variance indicator}

Bagozzi and Yi (1998) in Ghozali and Fuad (2005) have shown that out-off level is 0.6, meaning that composite reliability or construct reliability is quite favorable. Hypothesis test is a statistic method used to ensure that if $\mathrm{H} 1$ is correct, then $\mathrm{H} 0$ is wrong. By this test, the relationship between two variables can be known. Hypothesis test in SEM can be observed from fit index model. The tested hypothesis was:

H0: $\Sigma=\Sigma(\theta)$ against $\mathrm{H} 1: \Sigma \neq \Sigma(\theta)$

$\Sigma$ is a matrix of input, while $\Sigma(\theta)$ is a matrix of estimation. H0 says that matrix of estimation from SEM can better represent the data properly, while $\mathrm{H} 1$ suggests for matrix of input. The analysis on satisfaction assessment is done with descriptive qualitative method. This analysis involves attributes used to assess satisfaction, such as facility, condition, procedure, professionalism, and attitude toward service. Structural Equation Modeling (SEM) is a statistic technique that can analyze latent variable, indicator variable, and direct measurement of mistake. Latent variable is an abstract concept that is only observed indirectly through its effect on observed variables (indicators). Indicator variable is one that has been observed or measured empirically.

Structural Equation Modeling (SEM) is the second generation in multivariate analysis technique (Ghozali and Fuad, 2005) that allows the author to examine the relationship between complex variables, either recursive and nonrecursive, to obtain comprehensive description about the model. Data analysis will explains the effect of work achievement appraisal and employee rank promotion. Data are processed with a software WARP PLS.5.

Suartha (2013) explains that Structural Equation Modeling (SEM) is a statistical technique that allows some relatively complex relationships to be tested simultaneously. A complex relationship can be developed by one or some dependent variables or with one or few independent variables. One variable plays multiple roles, either being independent variable in a relationship, or being dependent variable in other relationship, recalling a fact that there is 
a stratified causality relationship. Each dependent and independent variable takes form as factor (or construct, made from some indicator variables). These variables are observed singular variables, or directly measured in a process. Ghozali and Fuad (2005) propose an index showing that a model is really fit without giving warranty that the model is truly fit. Conversely, when fit index states that a model is very bad, then it does not give a warranty that the model is truly not fit.

\section{Result And Discussion:-}

Structural Model of The Effect of Solidity and Integrity on Professionalism and The Impact of Professionalism on Integrity Leadership of TNI-AD

Structural model involves Partial Least Square. It refers to a construct model which is aimed to develop a theory that would be useful to further the existing model. PLS-SEM is designed to attest predictive relationship across the constructs by examining whether there is a relationship or an effect between these constructs. The use of PLS-SEM brings a consequence, respectively that it is conducted without strong theoretical base by disregarding parameteric and non-parameteric assumptions. The predicted model precision can be presumed from coefficient of determination (R-Square). PLS-SEM must be very appropriate in a research aimed to develop a theory. In SEM method, some variables are considered, and these are predictor variable, response variable, and mediator variable. Mediator variable is a connecting variable between predictor variable and response variable. Mediator variable can change into response variable if it is affected by predictor variable, and also can become predictor variable if it influences response variable.

Mediator variable is also called as intervening variable because theoretically it influences the observed phenomena (endogenous variable). This effect can be explained through the effect of relationship between exogenous variable and its phenomena. If exogenous variable is not anymore influential to endogenous variable after controlling mediator variable, then there will be perfect or complete mediation. If the effect of exogenous variable on endogenous variable is decreasing, but it still differs from 0 after controlling mediator variable, therefore, there will be partial mediation (Jogiyanto and Abdillah, 2009).

The author uses WarpPLS as a tool to process statistic data. Reason why it is used is that it helps author to understand the effect of variables with certain degree of complexity because it involves constructs and recursive indicators. Variance approach must be used to make the load of each item observable. The author expects this approach shall be helpful in understanding loading value that can represent latent variable as the predictor that will influence response variable. The following is a structural model describing the Effect of Solidity and Integrity on Professionalism and the Impact of Professionalism on Integrity Leadership of TNI-AD. 


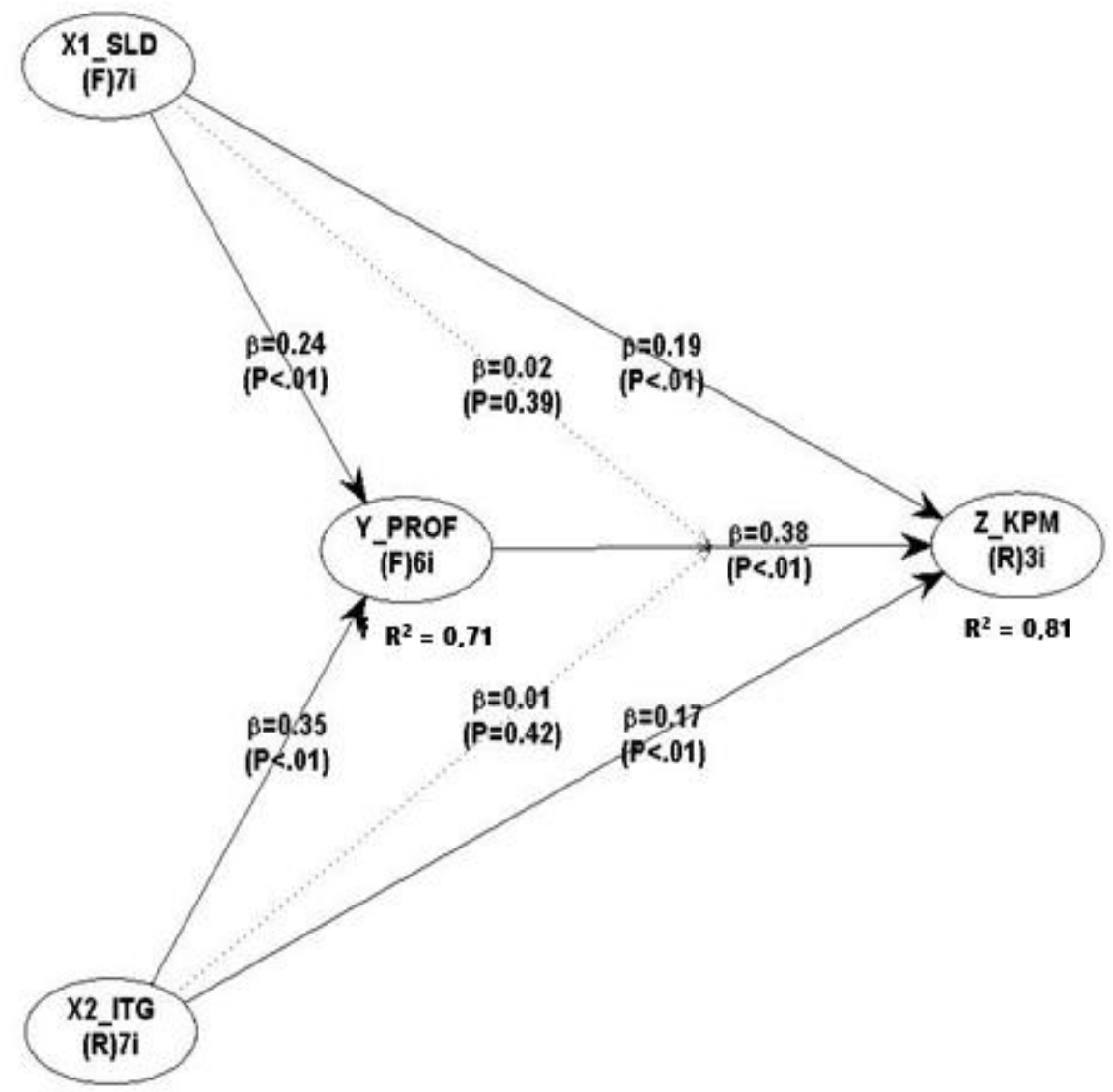

Figure 1:- Path Interpretation

\section{Implication of Result of Research:-}

As shown by result of data analysis with WarpPLS.5, it is known that solidity and integrity have effect rate of $71.2 \%$ on professionalism. Beta coefficient rate of solidity, that is represented by feeling as having similar fate and profession, is 0.290 . Both numbers indicate a fact that the increase for 1 unit of individual feeling as having similar fate and profession, then professionalism of soldiers will increase to 0.290. The latent variable of integrity is normative in nature with the highest load, and therefore, it has a positive and very significant effect on TNI-AD soldiers' sense of authority. Both solidity and integrity have effect of $72.12 \%$ on professionalism.

Data analysis with WarpPLS.5 indicates some results. Solidity is represented by feeling as having similar fate and profession. The effect of professionalism on integrity leadership is rated as $81 \%$. Beta coefficient rate of solidity is 0.333 . The increase for 1 unit of a feeling as having similar fate and profession would increase integrity leadership for 0.333 . Latent variable of integrity, represented by sense of authority, has positive effect on integrity leadership in charismatic style by rate of 0.331 . It means that the increase of integrity by 1 unit would increase integrity leadership by 0.331 .

The effect of professionalism can increase integrity leadership. The increase by 1 unit for TNI-AD soldiers to have identity recognition and developmental chance, then integrity leadership also have possible increase by 0.495 .

\section{Conclusion And Suggestion}

Regarding to the result of research and discussion, then conclusions and suggestions are explained as follows:

\section{Conclusion:-}

1. Solidarity and integrity have effect rate of $71.2 \%$ on professionalism. Solidity is represented by a feeling as having similar fate and profession. Professionalism is influential to integrity leadership by rate of $81 \%$. 
2. Normative integrity has the highest load, and it has a positive and very significant effect on sense of authority constituting the form of integrity among TNI-AD soldiers. Integrity is represented by soldiers' sense of authority, and it has positive effect on integrity leadership of charismatic style. The effect of professionalism may increase integrity leadership where the higher increase of identity recognition and chance toward development among TNI-AD soldiers, it will help developing integrity leadership.

\section{Suggestions:-}

Based on the conclusions above, it is suggested that:

1. The activities that support solidity must be created, and these must be still related with leader integrity to avoid polemics during the fast incoming information. It helps changing the undeveloped mindset of soldiers into the sophisticated one before it becomes serious threat to TNI-AD.

2. The change of mindset would change attitude, mentality, and behavior of soldiers who may create new culture which can influence their conduct of duty. Soldiers' attitude toward leader may change the existing ethic and norm professed by TNI-AD soldiers.

\section{References:-}

1. Avolio, B. and Kahai, S. (2003). Placing the "E" in E-Leadership: Minor Tweak or Fundamental Change. Dalam S. Murphy \& Riggio (Eds.), The Future of Leadership Development, hal. 49-70. New Jersey: Lawrence Erlbaum.

2. Bob Waworuntu , 2003. Determinan Kepemimpinan. Makara, Sosial Humaniora, Vol. 7, No. 2, Desember 2003

3. Compton, J.R. (2004). Shocked and Awed: The Convergence of Military and Media Discourse. Makalah yang dipaparkan di konferensi International Association for Media and Communication Research, Porto Alegre, Brazil, 25-30 Juli, 2004.

4. Daryanto, Arif, (2005), "Model Kepemimpinan dan Kepemimpinan Agribisnis Masa Depan".

5. Farmer, S.W. (2011). Servant leadership attributes in senior military officers: A qualitative study examining demographic factors. Cambridge, Proquest: UMI Dissertation Publishing.

6. Risdhianto, A, 2013. Profesionalisme Prajurit Sebagai Faktor Penentu Soliditas Dan Integritas TNI AD. Jurnal Yudhagama. Volume 34 No. II Edisi Juni 2014.

7. Sumitra, N, 2013. Kepemimpinan Militerdi Era Transformasi Angkatan Darat (Suatu tinjauan psikologi). Jurnal Yudhagama. Volume 33 No. I Edisi Maret 2013

8. Sihotang, Kasdin (2003), “Urgensi Pemimpin Transformatif”, Penerbit. PT. Suara Pembaharuan

9. Tohari, H, 2013. Signifikansi Peran Pemimpin Transformasional Dalam Proses Transformasi TNI AD. Jurnal Yudhagama. Volume 33 No. I Edisi Maret 2013

10. Schwartz, Janet S., David R. Segal. 1981. "Professional Autonomy of the Military in the United States and the Soviet Union". Air University review.

11. Segal. David R. and Janet S. Schawartz. 1981. "Professional Autonomy of Military in the United States and the Soviet Union". www.airpower.maxwell.af.mi

12. Janowitz, Morris. 1977. "Military Institutions and Coercion in the Developing Nations. Chicago and London": University of Chicago Press.

13. Widyatmini dan Luqman Hakim, 2008. Hubungan Kepemimpinan, Kompensasi Dan Kompetensi Terhadap Kinerja Pegawai Dinas Kesehatan Kota Depok. Jurnal Ekonomi Bisnis No. 2 Vol. 13, Agustus 2008. 